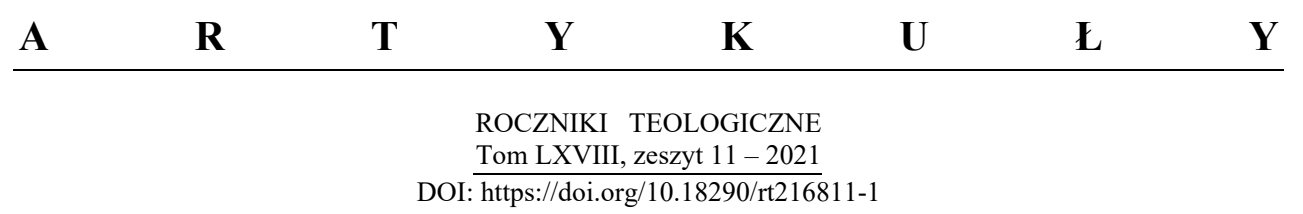

KS. MARIAN ZAJĄC

\title{
WPEYW KARDYNAŁA STEFANA WYSZYŃSKIEGO NA DUCHOWĄ PEDAGOGIZACJĘ NARODU
}

\author{
THE INFLUENCE OF CARDINAL STEFAN WYSZYŃSKI \\ ON THE SPIRITUAL PEDAGOGY OF THE NATION
}

\begin{abstract}
A b stract. The article aims to present the unique work of Cardinal Stefan Wyszyński, the Primate of the Millennium. A scholarly reflection on this topic was prompted by the fortieth anniversary of his death and his beatification on 12 September 2021. The modern history of Poland sees him as a prudent pastor of souls and teacher, a sensitive conciliar theologian, original social activist, exceptional writer, and relentless defender of the Catholic Church, which he headed as Primate of Poland. Wyszyński developed and indefatigably implemented Marian pedagogy of the nation, which became a category, method and motive of pastoral ministry in the time of communist enslavement, enabling the attainment of not only religious goals but also social, political, and cultural ones. On his initiative, the idea of commencing the Great Millennium Novena and committing the nation to the motherly slavery to Mary was developed, and the idea of Visitation of Our Lady of Czestochowa in Her image in all parishes in Poland. Ultimately, this strategy led to the purging of the nation's memory of atheistic indoctrination and the re-establishment of the spiritual bond with the Christian tradition of Poland. His constant inspirations gave rise to a new programme of pastoral and catechetical and preaching work, which was a great success. And although Cardinal Wyszynski has been absent from the Polish socioreligious space for forty years now, his message can inspire greater concern for the religious pedagogy of the nation, since his methodological instruments are still available.
\end{abstract}

Keywords: Stefan Wyszyński; theology; Marian pedagogy; patriotism; Catholic social teaching.

Pamięć o przeszłości zyskuje najbardziej na swoim znaczeniu, kiedy można ją wykorzystać w służbie teraźniejszości i przyszłości. Wszelkie inspiracje

Ks. prof. dr hab. Marian Zając - Katedra Katechetyki Integralnej, Wydział Teologii, Katolicki Uniwersytet Lubelski Jana Pawła II; adres do korespondencji: Al. Racławickie 14, 20-950 Lublin; e-mail: marian.zajac@kul.pl; ORCID: https://orcid.org/0000-0002-2940-5154. 
wychowawcze, wydobywane z przeszłości, powinny być przydatne w rozwiązywaniu współczesnych trudności. Dlatego po czterech dekadach, jakie upłynęły od śmierci Kardynała Stefana Wyszyńskiego, „Prymasa Tysiąclecia” i w kontekście jego beatyfikacji 12 września 2021 roku, warto przywołać jego osobę oraz unikalne dokonania w wielu przestrzeniach życiowych polskiego narodu. Przekaz historyczny ukazuje go jako człowieka o słabej konstrukcji fizycznej i zdrowotnej, ale jednocześnie prawdziwego giganta ducha, który dał się poznać nie tylko jako roztropny duszpasterz i teolog, ale także jako oryginalny społecznik i zdolny publicysta. Jednocześnie zasłynął jako dobry pasterz, niestrudzony nauczyciel i nieugięty obrońca Kościoła katolickiego ${ }^{1}$. Stanisław Żaryn stwierdził: „Takiego ojca, pasterza i prymasa Bóg daje raz na tysiąc lat" ". Jego postawa, nie cofająca się przed przyjęciem prześladowania i więzienia w służbie Ewangelii, dała mu moralne prawo do tego, aby w trudnych czasach wziąć na swoje barki rolę wychowawcy naro$\mathrm{du}$, autentycznego strażnika sprawiedliwości społecznej oraz wytrwałego obrońcy człowieka.

\section{SOBOROWY TEOLOG WRAŻLIWY NA ZNAKI CZASU}

W dobie gwałtownych przemian społeczno-kulturowych, niosących ze sobą niedocenianie roli instytucji religijnych oraz znaczenia autorytetu wybitnych jednostek w życiu Kościoła i narodu, należy cierpliwie tłumaczyć na podstawie konkretnych przykładów ich znaczenia dla funkcjonowania zbiorowości ludzkiej. W aktualnej sytuacji Kościół katolicki, pomimo obiektywnych trudności w realizacji swojej misji zbawczej, podkreśla znaczenie wybitnych ludzi, którzy przez swoje niestandardowe działanie wywarli wielki wpływ na jakość życia religijnego, społecznego i rodzinnego narodu ${ }^{3}$. Czyni to w przekonaniu, że ich aktywność ma wciąż walor inspirujący do przemiany aktualnej rzeczywistości w świetle Ewangelii ${ }^{4}$. Papież Franciszek certyfikuje takie myślenie o przeszłości, kiedy przywołuje św. Józefa jako osobowy

\footnotetext{
${ }^{1}$ Por. Kardynat Stefan Wyszyński. Droga życia i postugi pasterskiej, red. R. Czekalski (Warszawa: Wydawnictwo Naukowe UKSW, 2021), 5.

${ }^{2}$ Jan Żaryn, Dzieje Kościoła katolickiego w Polsce (1944-1989) (Warszawa: Wydawnictwo Neriton, 2003), 463.

${ }^{3}$ Por. Kardynat Stefan Wyszyński, Droga życia i postugi pasterskiej, 5.

${ }^{4}$ Por. List apostolski Patris corde Ojca Świętego Franciszka z okazji 150. rocznicy ogłoszenia Świętego Józefa Patronem Kościoła Powszechnego 8 grudnia 2020 (Tarnów: Wydawnictwo Biblos, 2020), 7.
} 
wzór postępowania wydobyty z historii i przekonuje, że „nasze życia są tkane i wspierane przez zwykłe osoby - zazwyczaj zapominane - które nie występują w tytułach gazet i magazynów, ani na wielkiej scenie ostatniego show, lecz niewątpliwie dziś zapisują decydujące wydarzenia na kartach naszej historii" ". Papież także przypomina, że tacy ludzie jak św. Józef, którzy są pozornie ukryci lub na „drugiej linii”, mają wyjątkowy udział w historii zbawienia, dlatego im wszystkim należy się słowo uznania i wdzięczności. Taka papieska narracja, niejako ex post, znakomicie charakteryzuje osobę i dzieło ks. kardynała Stefana Wyszyńskiego, który oddając siebie na wyłączną służbę Bogu w kapłaństwie, w sposób wyjątkowy uczynił ze swojego życia służbę ludziom w Polsce ${ }^{6}$.

Swoją działalność rozwinął w okresie, kiedy od strony politycznej ujawniało się dążenie do walki z całym polskim nurtem niepodległościowym i Kościołem katolickim. Szczególnie szkodliwa okazała się przebiegła pragmatyka angażowania $\mathrm{w}$ realizację ateizujących zadań obywateli polskich i uporczywe dyskryminowanie ludzi wierzących ${ }^{7}$. W takiej rzeczywistości kardynał Wyszyński, jako teolog i duchowy wizjoner, znalazł ideę mariologiczną, wokół której rozwinął swoją wielowymiarową działalność ${ }^{8}$.

Z wielkim rozmachem zostały podjęte przez kardynała Stefana Wyszyńskiego działania katechetyczne, zorientowane na świętowanie Tysiąclecia Chrześcijaństwa i Wielką Nowennę, które przyniosły także wskazania dla maryjnej pedagogizacji narodu polskiego. Reakcją władz politycznych na to stanowisko było podjęcie zdecydowanego ataku na Kościół oraz uwięzienie prymasa S. Wyszyńskiego. Okres ten można nazwać „czarnymi latami” Kościoła w Polsce 9 . Nieco wcześniej, jako Prymas Polski, szukał oficjalnego porozumienia z rządem komunistycznym, aby w razie naruszania praw katolików, można było powołać się na określone regulacje prawne ${ }^{10}$. Po trudnych negocjacjach porozumienie podpisano na forum Komisji Mieszanej 14 kwietnia 1950 r. Ważną częścią tego porozumienia była sprawa nauczania religii

\footnotetext{
${ }^{5}$ Tamże, 6.

${ }^{6}$ Por. Małgorzata Laskowska, „Postulaty etyczne dla mediów w publicystyce ks. Stefana Wyszyńskiego,” Kultura-Media-Teologia 3(2010), 92.

${ }^{7}$ Zygmunt Zieliński, „Zasady polityki państwa wobec Kościoła w Polsce w latach 1944-1956”, w Aparat ucisku na Lubelszczyźnie latach 1944-1956 wobec duchowieństwa katolickiego, red. Zygmunt Zieliński (Lublin: Towarzystwo Naukowe KUL, 2000), 8-9.

${ }^{8}$ Czesław Bartnik, Matka Boża (Lublin: Towarzystwo Naukowe KUL, 2003), 337.

${ }^{9}$ Por. Czarna księga komunizmu, red. Stéphan Courtois (Warszawa: Wydawnictwo AA, 1999), 13.

${ }^{10}$ Andrzej Micewski, Kardynat Wyszyński prymas i mąż stanu (Paryż: Societe D’Editions Internationales, 1982), 58.
} 
w szkołach państwowych różnego stopnia ${ }^{11}$. Prymas dążył jednocześnie do zachowania ścisłych związków między Kościołem katolickim a narodem ${ }^{12}$. W opinii kardynała Wyszyńskiego, jedyną realną alternatywą było dążenie do zachowania tożsamości maryjnej narodu, według wskazań kard. Augusta Hlonda ${ }^{13}$. Nazywając Hlonda prymasem maryjnym powiedział: „Ta żywa wiara w potęgę Matki Najświętszej była dla mnie - jako Jego następcy - zobowiązująca. Wydało mi się, że mam wszystko uczynić, co w ludzkiej mocy leży, aby to własne prorocze widzenie umierającego Prymasa się urzeczywistniło" 14 . Od tego czasu rozwinęła się strategia pedagogizacji religijnej narodu polskiego, która była formą łączenia mariologii soborowej z działalnością katechetyczną i duszpastersko-społeczną w trudnych czasach komunizmu w Polsce ${ }^{15}$.

\section{NAUCZYCIEL I KATECHETA Z PROFILEM MARYJNYM}

W okresie powojennym kardynał Stefan Wyszyński, jako kanonista i socjolog katolicki, zbyt dobrze znał odmienność natury i celów Kościoła i państwa, aby dążyć do ich politycznej symbiozy. W ratowaniu dziedzictwa religijnego w narodzie polskim oparł się więc na wierze i przekonaniach religijnych prostego ludu, uczestniczącego w masowych uroczystościach religijnych i katechizacji. Przekonywał także, że duchowy przełom w Polsce oraz odnowienie moralne katolików stanie się możliwe, gdy będzie mu patronować Maryja $^{16}$. Nie potrzebna mu była do tego żadna nowa doktryna duszpasterska ani ideologia polityczna, ale wystarczyło umiejętne wykorzystanie żywot-

${ }^{11}$ Por. Hanna Konopka, 17 lat nauczania religii w Polsce Ludowej (wybór dokumentów) (Białystok: Wydawnictwo Uniwersytetu w Białymstoku, 1998), 21.

${ }^{12}$ Por. Chrześcijańska nauka o narodzie wedlug prymasa Stefana Wyszyńskiego, red. Czesław Bartnik (Lublin: Redakcja Wydawnictw Katolickiego Uniwersytetu Lubelskiego, 1982), 8.

13 „Uważam się nie tylko za następcę Kardynała Hlonda na stolicy gnieźnieńskiej i warszawskiej. Uważam się również za wykonawcę, aby wszystko, co się dzieje w Polsce dla obrony Kościoła Chrystusowego, było pod opieką Najświętszej Maryi Panny, ponieważ zaufał, że w Jej imię nastąpi zwycięstwo”. Kard. Stefan Wyszyński, „Żywa wiara w potęgę Maryi była dla niego zobowiązaniem. 23 października 1967", w Kardynat August Hlond Prymas Polski, red. Wojciech Necel (Poznań: Wydawnictwo Święty Wojciech, 1993), 23

14 Tamże, 27.

${ }^{15}$ Por. Jerzy Lewandowski, „Wychowawcze aspekty Wielkiej Nowenny w nauczaniu kard. S. Wyszyńskiego”, Chrześcijanin w Świecie 116(1983): 16.

${ }^{16}$ Por. Władysław Miziołek, „Maryjna koncepcja duszpasterstwa kardynała Stefana Wyszyńskiego", Ateneum Kapłańskie 97(1981): 255. 
nych tradycji narodu i chrześcijański system wartości oparty na założeniach Dekalogu ${ }^{17}$.

W rozważaniach nad maryjną pedagogizacją narodu w ujęciu Prymasa Wyszyńskiego Cz. Bartnik stwierdza: „Maryja stała się kategorią, metodą i motywem duszpasterstwa, które nie biło wprost w dogmaty ateizmu marksistowskiego, nie było tematyką walczącą politycznie, nie naruszało żadnych praw komunistycznych, ale osiągało owoce nie tylko religijne, lecz także i społeczne, polityczne i kulturalne"18. Wprowadzenie do działalności zbawczej polskiego Kościoła treści maryjnych doskonale odpowiadało polskim tradycjom, ożywiało religijność, miało także bardziej praktyczny charakter. W takiej działalności tzw. „kategoria maryjna” przekazu nie została zacieśniona przez Prymasa tylko do świata jednostki, jak to uczyniono w katechezie i teologii na zachodzie Europy, ponieważ on rozciągnął ją na życie społeczne narodu, otwierając nowe perspektywy ewangelizacyjne. W ten sposób w przekazie katechetycznym i duszpasterskim zyskał w Maryi motyw oraz bezpieczną metodę skutecznego rozwiązywania kwestii społecznej, politycznej i moralnej ${ }^{19}$.

Kardynał Stefan Wyszyński najpierw zapowiedział, a następnie potwierdził maryjną strategię wychowawczą skierowaną do ateizowanego narodu polskiego, wypowiadając słowa: „Wszystko postawiłem na Maryję”. Ta deklaracja dotyczyła nie tylko jego osobistego życia, ale w obszar oddziaływania Maryi został oddany los narodu, Kościoła i katechizacji w Polsce ${ }^{20}$. Pełne symbolicznych epizodów związanych z Maryją były koleje życia przyszłego Prymasa Polski. W czasie studiów w Seminarium Duchownym we Włocławku zbliżył się duchowo do kultu Maryi w Jasnogórskim Wizerunku, kiedy na jego oczach pierwszą „Wielką Nowennę Narodu” przeprowadził na Jasnej Górze paulin o. Aleksander Łoziński. Wtedy ks. Wyszyński był świadkiem ogólnonarodowego dziękczynienia za cud nad Wisłą 15 sierpnia 1920 r., który ocalił suwerenność narodową. Trudno się wobec tego dziwić, że w sytuacji wielorakiego zagrożenia, z którym musiał się zmierzyć sprawując funkcję prymasa, pobożność maryjna stała się dla niego najskuteczniejszym ratunkiem ${ }^{21}$.

\footnotetext{
${ }^{17}$ Por. Micewski, Kardynat Wyszyński, prymas i mą̇ stanu, 441.

${ }^{18}$ Bartnik, Matka Boża, 337.

19 Tamże.

${ }^{20}$ Janusz. Królikowski, „Maryja - Matka Kościoła w nauczaniu kardynała Stefana Wyszyńskiego", Collectanea Theologica 61(1991), 4: 81.

${ }^{21}$ „List pasterski Biskupów Polskich do rodziców, dzieci i młodzieży katolickiej o nauczaniu prawd wiary 2 września 1961”, w Listy Pasterskie Episkopatu 1945-2000. Część I, red. Piotr Libera, Andrzej Rybicki, Sylwester Łącki (Marki: Wydawnictwo Michalineum, 2003), 244.
} 
Po aresztowaniu, 8 grudnia 1953 r. w Stoczku Warmińskim, kardynał Wyszyński dokonał aktu całkowitego oddania się Matce Bożej, a przez Nią Bogu. W cierpieniu i samotności narodziła się maryjna strategia ratunku dla Polski poprzez odnowienie Ślubów Jasnogórskich w trzechsetną rocznicę ich złożenia przez króla Jana Kazimierza. W więzieniu powstała także myśl o rozpoczęciu Wielkiej Nowenny Tysiąclecia, oddaniu narodu w macierzyńską niewolę Maryi oraz pomysł Nawiedzenia Matki Bożej Częstochowskiej w Jej wizerunku wszystkich parafii w Polsce ${ }^{22}$.

Tym samym rozpoczął się okres bezprzykładnego rozkwitu pedagogizacji maryjnej narodu, poprzez którą nie tylko przygotowywano, ale przede wszystkim pogłębiono rezultaty nawiedzenia. Było to maryjne wydarzenie, które wskazało Kościołowi kierunek działania, gdy po latach bezbożnego działania władzy komunistycznej, naród ślubował wierność Bogu i Matce Najświętszej. Za sprawą kardynała Wyszyńskiego katolicyzm polski po dziesięciu latach od zakończenia II wojny światowej przeżywał etap wyraźnego wewnętrznego wzmocnienia pod przewodnictwem Matki Bożej.

Najbardziej zwięzłą diagnozę, a jednocześnie cenne świadectwo na temat roli maryjnego Prymasa Tysiąclecia dla Kościoła katolickiego i narodu polskiego, wystawił Jan Paweł II bezpośrednio po swoim wyborze na Stolicę Piotrową w Rzymie. Papież podkreślił rolę jego zawierzenia bez reszty Matce Kościoła. Docenił preferowanie duchowości maryjnej, która była wewnętrzną zasadą organizującą działalność duszpastersko-katechetyczną Kościoła w Polsce. W tym upatrywał główną przyczynę ocalenia narodu polskiego oraz własny wybór na następcę świętego Piotra w Rzymie ${ }^{23}$. Słuszność zwrotu w pedagogizacji religijnej narodu oraz katechizacji w kierunku duchowości maryjnej kardynała Wyszyńskiego była także wielokrotnie potwierdzana przez Jana Pawła II podczas jego wizyt duszpasterskich do Ojczyny. Dokonał on oficjalnej afirmacji jego zawierzenia Maryi i sojuszu działalności zbawczej Kościoła w Polsce z Matką Jego Założyciela, czczoną od wieków w Jasnogórskim Obrazie ${ }^{24}$.

\footnotetext{
22 Por. Stefan Wyszyński, Idzie nowych ludzi plemię (Poznań-Warszawa: Pallotinum, 2001), 9.

${ }^{23}$ „Czcigodny i Umiłowany Księże Prymasie! Pozwól, że powiem po prostu co myślę. Nie byłoby na Stolicy Piotrowej tego Papieża-Polaka, który dziś pełen bojaźni Bożej, ale i pełen ufności, rozpoczyna nowy pontyfikat, gdyby nie było Twojej wiary, nie cofającej się przed więzieniem i cierpieniem. Twojej heroicznej miłości. Twojego zawierzenia bez reszty Matce Kościoła; gdyby nie było Jasnej Góry i tego całego okresu dziejów Kościoła w Ojczyźnie naszej, który związany jest z Twoim biskupim, prymasowskim posługiwaniem”. Podaję za: Micewski, Kardynat Wyszyński, prymas i mąż stanu, 394.

${ }^{24}$ Por. Jan Paweł II, „Homilia w czasie liturgii Słowa (Częstochowa 2 czerwca 1997)”, w Jan Pawet II. Pielgrzymki do Ojczyzny, red. Janusz Poniewierski (Kraków: Wydawnictwo Znak, 2005), 939.
} 


\section{WIZJONER PEDAGOGIZACJI MARYJNEJ NARODU}

Z inicjatywy kardynała Stefana Wyszyńskiego osoba Maryi stanęła w centrum odpowiedzialności za każdego członka Kościoła i obywatela narodu polskiego. W stosunku do Kościoła Maryja była - zdaniem Wyszyńskiego - wzorem troski o jego egzystencję i rozwój ${ }^{25}$. Natomiast w odniesieniu do całego narodu polskiego stała się członem integrującym społeczność narodową poprzez tysiącletnią historię. Wielka Nowenna kryła w sobie wezwanie do głębokiego rachunku sumienia całego chrześcijańskiego narodu ${ }^{26}$. Efektem końcowym oczyszczenia pamięci miało być ponowne nawiązanie duchowej więzi z chrześcijańską tradycją Polski, z jej przeszłością, oficjalnie deprecjonowaną i ośmieszaną przez reżim komunistyczny. Była ona pomyślana jako przygotowanie narodu chrześcijańskiego na czekające go wyzwania poprzez dzieło kompleksowego odnowienia duchowego, religijnego, moralnego i społecznego. Temu odrodzeniu serc i ducha miał służyć na płaszczyźnie „mistyki polskiej” kult maryjny. Kardynał Wyszyński postulował: „Potrzeba naszemu narodowi, aby rozkochał się w ideale Maryi! Nie wystarczy patrzeć w Jej czyste oblicze, choćby zranione, ale trzeba w Jej oczach wyczytać wszystko, co potrzebne jest do odnowy życia narodowego" ${ }^{" 27}$. Ślady przemiany miały pozostać w ludzkich sercach i dalekosiężnych planach, aby Polska była chrześcijańska nie tylko z imienia, ale z wyznania, $\mathrm{z}$ wiary, z życia i czynu ${ }^{28}$. Na tym polegały założenia przygotowane przez kardynała Stefana Wyszyńskiego na Tysiąclecie Chrześcijaństwa i Wielką Nowennę.

Inicjujący całą działalność akt zawierzenia objął nie tylko biskupów i kapłanów wraz z miejscami ich modlitwy, ale także wszystkich rodziców i domy rodzinne, młodzież i dzieci oraz zagrożone laicyzacją szkoły, wszystkie miasta i wioski. Nie pomijał także ludzi słabych w wierze, pozbawionych

${ }^{25}$ Stefan Wyszyński, „Dlaczego zaczynamy od Maryi. Przemówienie inauguracyjne podczas Kursu Maryjnego. Jasna Góra 6 października 1959”, w Stefan kard. Wyszyński Prymas Polski, Wszystko postawiłem na Maryje (Paris: Societe D’Editions Internationales, 1980), 164.

${ }^{26}$ Stefan Wyszyński, Wielka Nowenna Tysiaclecia (Paris: Societe D’Editions Internationales, 1962), 3 .

${ }^{27}$ Stefan kardynał Wyszyński prymas Polski, Gody w Kanie (Paris: Societe D’Editions Internationales, 1962), 72.

${ }^{28}$ Nowenna, odwołująca się do tradycji duchowości maryjnej, miała także za zadanie obronę kultury narodowej i chrześcijańskiej. Zdaniem Prymasa utrata kultury byłaby największą stratą, która prowadzi do tego, że naród staje się niemym, zalęknionym i trwożliwym, a tym samym ginie. Zob. Stefan Wyszyński, Z rozważań nad kultura ojczysta (Warszawa-Poznań: Wydawnictwo Pallotinum, 1979), 244. 
miłości, a także tych, którzy organizowali walkę z Bogiem, Kościołem i religią. Opisując działanie Maryi w realizacji programu Wielkiej Nowenny i Ślubów Narodu, Prymas Wyszyński wezwał do naśladowania Bożej linii postępowania i do złożenia nadziei w Zwycięskiej Matce Boga, której Bóg Ojciec i Syn Boży oddali do dyspozycji to, co mieli najdroższego, czyli pośrednictwo w rozdzielaniu laski ${ }^{29}$.

Dnia 15 marca 1961 roku w Warszawie oddali się Matce Bożej w macierzyńską opiekę wszyscy biskupi polscy ${ }^{30}$. Natomiast 4 września 1961 roku na zakończenie rekolekcji Episkopatu Polski kardynał Wyszyński razem ze wszystkimi biskupami, w Kaplicy Matki Bożej Jasnogórskiej, oddał uroczyście całą Polskę „i wszystko, co Polskę stanowi” w świętą niewolę miłości Maryi Królowej Polski. Na zakończenie „Aktu oddania”, specjalnie na tę uroczystość napisanego, Prymas i biskupi obiecywali Maryi, że jeśli Ona uratuje zagrożoną katechizację dzieci i młodzieży, i jeżeli obroni seminaria duchowne, bez których Kościół nie może się rozwijać, wtedy oni - biskupi na czele z Prymasem - w Roku Milenijnym oddadzą raz jeszcze Polskę w niewolę Maryi. A uczynią to w obliczu całego narodu, wiążąc nieodwracalnie los duszpasterstwa i katechizacji z Maryją ${ }^{31}$. Biskupi polscy dotrzymali złożonych obietnic, ponieważ 3 maja 1966 roku został dokonany przed obrazem Matki Boskiej Częstochowskiej Akt oddania się narodu w macierzyńską niewolę Maryi za wolność Kościoła Chrystusowego.

Bez wahania można potwierdzić, że Akt oddania był także wyznaniem wiary w Boże dzieło Odkupienia, które spełniało się w przeszłości na polskiej ziemi. Od tej modlitewnej retrospekcji Akt jasnogórski przechodził następnie ku przyszłości, ponieważ biskupi w trosce o Kościół w drugim tysiącleciu, chcieli zawierzyć jego sprawy Maryi. Akt jasnogórski był równocześnie modlitwą zawierzenia, skierowaną do Maryi Dziewicy jako Matki Syna Bożego oraz Matki Kościoła i Królowej Polski. Motywem zawierzenia były racje teologiczne przypomniane przez konstytucję Lumen gentium, a także tysiącletnie doświadczenie chrześcijańskie poparte świadomością, że dzięki Maryi została uratowana wiara narodu ${ }^{32}$.

${ }^{29}$ Stefan Wyszyński, „Oddajemy Tobie, Maryjo. Modlitwa przed Cudownym Obrazem Matki Bożej Jasnogórskiej. Jasna Góra 25 sierpnia 1960”, w Stefan kard. Wyszyński Prymas Polski, Wszystko postawilem na Maryję, 220-223.

${ }^{30}$ Stefan Wyszyński, „Znak jedności pasterzy Kościoła w Polsce: W dłoniach Maryi Wspomożycielki. (Przemówienie do Biskupów polskich w dniu ich oddania się Matce Boga Żywego. Warszawa 15 marca 1961”, w Stefan kard. Wyszyński Prymas Polski, Wszystko postawiłem na Maryję, 233.

${ }^{31}$ Por. Jerzy Tomziński, Dzieje Jasnej Góry i Cudownego Obrazu (Częstochowa: Wydawnictwo Paulinianum, 2015), 56.

${ }^{32}$ Stefan kard. Wyszyński Prymas Polski, Wszystko postawitem na Maryję, 262. 
$\mathrm{Na}$ treść przedmiotową aktu składały się trzy elementy. Najpierw sam akt, następnie jego treść oraz intencja jego podjęcia. Jasnogórskie oddanie w niewolę potwierdzało prawdę, że człowiek jako stworzenie zależy bezwzględnie od Boga - Stwórcy i nie może istnieć bez Niego. Natomiast zależność człowieka w życiu nadprzyrodzonym od Matki Chrystusowej zakłada Jej szczególny udział w Odkupieniu. Ponieważ sam Bóg przyszedł do ludzi w Chrystusie przez Maryję, zatem najodpowiedniejszą drogą dojścia ludzi do Boga jest Ona sama ${ }^{33}$.

Strategiczną intencją Aktu jasnogórskiego było rozszerzenie królestwa Chrystusowego na ziemi. Cel oddania Maryi oraz związana z nim intencja, wyrażona zwrotem «za Kościół» i «za wolność Kościoła w świecie i w Ojczyźnie», dotyczyła aktualnej wspólnoty Kościoła, gdzie Maryja stała się prawdziwą Matką i Orędowniczką. Kardynał Wyszyński pragnął obudzić przekonanie, że Bóg sam chce zbawienia ludzi, i że w Jego zbawczej ekonomii tkwią wszystkie środki do osiągnięcia tego celu. Natomiast oddanie się w niewolę Maryi trafiało w Bożą ekonomię zbawienia w punkcie, który leżał najbliżej chrześcijańskiego i katechetycznego doświadczenia ${ }^{34}$. Akt jasnogórski zawierał zobowiązanie do stałego umacniania i pogłębiania tego życia. Wszyscy wierzący zostali do tego zobowiązani na podstawie przyrzeczeń chrztu świętego, a przez Akt jasnogórski o tyle, o ile uczynili go wewnętrznie swoim. Należy tutaj podkreślić, że kardynał Wyszyński działał wtedy przede wszystkim jako pasterz i katecheta ${ }^{35}$. Historia pokazała, w jakiej mierze i w jaki sposób Akt jasnogórski wpłynął na maryjną pedagogizację narodu.

\section{NAJWAŻNIEJSZE EFEKTY MARYJNEJ PEDAGOGIZACJI}

Działalność maryjna kardynała Wyszyńskiego, „Prymasa Tysiąclecia”, może być dzisiaj oceniona z perspektywy minionych dekad. Złożone na Jasnej Górze Śluby narodu nie mogły wystarczyć, ponieważ ważniejsze od ślubowań było wprowadzenie ich treści w codzienne życie. Jednakże one „dały początek nowemu programowi pracy duszpasterskiej i katechetyczno-kazno-

\footnotetext{
${ }^{33}$ Por. tamże, 52-53.

${ }^{34}$ Zob. Jan Uryga, Nigdym Ja ciebie ludu nie rzuciła (Włocławek: Wydawnictwo Duszpasterstwa Rolników, 2001), 13.

${ }^{35}$ Por. Czesław Ryszka, Zwyciężyłaś, zwyciężaj. Matka Boża w dziejach narodu polskiego (Częstochowa: Edycja Świętego Pawła, 2003), 118.
} 
dziejskiej, który miał być realizowany w okresie Wielkiej Nowenny Milenijnej" ${ }^{36}$. Każdy jej rok rozpoczynał się od odnowienia ślubowań we wszystkich kościołach Polski, zawsze trzeciego maja lub w niedzielę po trzecim maja. Inspirujące znaczenie dla katechezy maryjnej miały hasła kolejnych lat nowenny ${ }^{37}$.

Realizacji programu Wielkiej Nowenny miała służyć peregrynacja kopii Obrazu Matki Bożej Częstochowskiej. Jej wizerunek, na osobistą prośbę kardynała Wyszyńskiego, pobłogosławił papież Pius XII w maju 1957 roku. Następnie rozpoczęła się peregrynacja, poprzedzana rekolekcjami parafialnymi. Jej duchowe owoce spotęgowały represyjne działania władz państwowych, które uwięziły obraz. Wtedy poprzez znak świecy, pustych ram i ewangeliarza potwierdziła się prawda, że istota Nawiedzenia nie polega na czci obrazu jako takiego, ale sięga głębszych pokładów duszy ludzkiej i stanowi mobilizację do duchowego działania ${ }^{38}$. Prymas Wyszyński zwracał także uwagę, że ślubowania wiążą indywidualnie wszystkich katolików, jako ludzi odkupionych, członków Mistycznego Ciała Chrystusa, którym jest Kościół. Konieczne zatem było zbudowanie przekonania o konieczności życia w łasce uświęcającej. To zadanie określił jako zawsze aktualne, a pracę nad jego wykonaniem jako istotną, zasadniczą oraz fundamentalną, bez której nie może mieć znaczenia żadna inna praca duszpasterska ${ }^{39}$.

Co zostało z odbytej pedagogizacji o profilu maryjnym, i dzisiaj może służyć przyszłości w polskich przestrzeniach życiowych katolików? Najważniejszym przesłaniem treściowym oraz najgłębiej zasymilowanym społecznie jest hasło: „stać na straży życia" ${ }^{40}$. W świadomości osób wierzących zostało przekonanie, że jest ono największym darem Boga. Równocześnie

36 Tamże.

${ }^{37}$ Rok I. 1957/58: „Wierność Bogu, Krzyżowi, Ewangelii, Kościołowi i jego Pasterzom”; Rok II. 1958/59: „Naród wierny łasce” - życie w łasce Bożej i przeciwstawianie się każdemu grzechowi; Rok III. 1959/60: „Życie jest światłością ludzi” - Rok życia, obrona życia duszy i ciała; Rok IV. 1960/61: „Małżeństwo - sakrament wielki w Kościele”; Rok V. 1961/62: „Rodzina Bogiem silna” - wychowanie w duchu Chrystusowym; Rok VI. 1962/63: „Młodzież wierna Chrystusowi”; Rok VII. 1963/64: „Abyście się społecznie miłowali” - sprawiedliwość i miłość społeczna; Rok VIII. 1964/65: „Nowy człowiek w Chrystusie” - walka z wadami narodowymi, pielęgnowanie cnót chrześcijańskich i narodowych; Rok IX. 1965/66: „Weź w opiekę Naród cały” - cześć Maryi jako Królowej Polski, tamże.

38 „Na zakończenie Ogólnopolskiego Nawiedzenia Obrazu Matki Boskiej Jasnogórskiej 27-28 czerwca 1980", w Listy Pasterskie Episkopatu 1945-2000. Część II, red. Piotr Libera, Andrzej Rybicki, Sylwester Łącki (Marki: Wydawnictwo Michalineum, 2003), 1293.

39 Tamże, 603.

40 Zob. „Biskupi Polscy wzywają do niesienia pomocy zagrożonej rodzinie, 31 października 1972”, w Listy Pasterskie Episkopatu. Część I, 910-914. 
tłumaczono, że aborcja jest zbrodnią przeciwko życiu i nie może być żadnego usprawiedliwienia dla zabójców, bez względu na ekstremalne okoliczności ich działania, ponieważ na straży ludzkiego życia stoi pozytywne prawo Boże ${ }^{41}$.

$\mathrm{Na}$ teren katechetyczny zostało przeniesione także orędzie o wartości małżeństwa i rodziny dla rodzącego i rozwijającego się życia. Przypominano, że życie ziemskie człowiek zawdzięcza swoim rodzicom, którzy współpracują z Bogiem w akcie stwórczym. Zadaniem chrześcijanina jest więc stać na straży nierozerwalności małżeństwa. W kontekście życia małżeńskiego pojawiło się kolejne milenijne hasło: „Rodzina Bogiem silna”. W piątym roku Wielkiej Nowenny przypomniano, że rodzina jest najmniejszą komórką społeczeństwa, a społeczeństwo jest takie, jakie są rodziny. Stąd wypływa szczególne zainteresowanie katechezy rodziną i jej problemami. Pierwszym zadaniem, wynikającym z Jasnogórskich Ślubów, było uporządkowanie i poprawianie podstawowych relacji międzyludzkich.

Kolejne zadanie odnosiło się do religijnego wychowania dzieci. Polegało ono na apelu, aby nie odkładać chrztu świętego pozbawiając dziecko pomocy nadprzyrodzonej łaski, przyzwyczajać wcześnie dziecko do modlitwy, do oznak czci Bożej, znaku krzyża, prowadzić do świątyni od najmłodszych lat. Starszym dzieciom wpajano wierność w modlitwie rannej i wieczornej, sumienność w uczeniu się prawd wiary, praktykę uczęszczania do kościoła na nabożeństwa i katechizację, czuwanie nad przygotowaniem do sakramentów świętych. Natomiast opuszczającym dom rodzinny należało podarować medalik, różaniec, książeczkę, Pismo Święte i utrzymywać z nimi łącznośćc ${ }^{42}$.

Pełną realizację Ślubów Jasnogórskich mogła zagwarantować walka z wadami narodowymi. W zamyśle kardynała Wyszyńskiego ósmy rok Wielkiej Nowenny poświęcony był problemowi wad narodowych i sposobom ich przezwyciężania. Wskazywano zatem, że należą do nich lenistwo, niedbałość, zmienność, wygodnictwo, rozrzutność i powierzchowność. Do wad Polaków należały także niechęć do pracy wspólnej, lekkomyślność wywołana niepewnością bytowania, marnotrawstwo wobec niepewnego jutra, pijaństwo i rozwiązłość, drobne kradzieże, brak poszanowania dobra publicznego, niewierność wobec zobowiązań. Jako przedmiot walki szczególnej wskazywano na lenistwo i lekkomyślność, marnotrawstwo, pijaństwo i rozwiązłość ${ }^{43}$.

\footnotetext{
${ }^{41}$ Zob. „Roczny plan nauki religii klas VIII-XII”, Katecheta 5(1958): 409.

${ }^{42}$ Por. Jan Siedlarz, „Wielka Nowenna Tysiąclecia - program społeczny na dziś”, Currenda 151(2001): 599.

${ }^{43}$ Stefan Wyszyński, Wielka Nowenna Tysiąclecia (Paris: Societe D’Editions Internationales, 1962), 304.
} 
Praca nad zwalczaniem wad i zdobywaniem cnót została określona przez kardynała Wyszyńskiego jako bój najcięższy i najświętszy, bo pole walki jest w ludzkich sercach, myślach i woli.

Zaplanowane przez kardynała Stefana Wyszyńskiego elementy programu Wielkiej Nowenny Tysiąclecia mają dla pedagogizacji religijnej w Polsce ponadczasową aktualność. Można też mówić o przedłużeniu nowenny w katechezie maryjnej, poprzez którą otrzymała ona swoją kontynuację. Pedagogizacji mariologicznej, realizowanej w katechezie maryjnej, towarzyszyły inne formy kultu i pobożności maryjnej. Po okresie stagnacji przebudził się na nowo ruch pielgrzymkowy, w szczególności na Jasną Górę. Rozwinęła się praktyka nawiedzenia Obrazu Matki Bożej Jasnogórskiej w diecezjach, parafiach, rodzinach, pokutno-błagalne akcje na rzecz zagrożonych odcinków życia moralno-religijnego w kraju oraz różnorodna pomoc dla Ojca Świętego. Chociaż skończyła się Wielka Nowenna, to jednak nie skończyła się bynajmniej akcja dalszej „pedagogizacji” narodu w ramach katechezy maryjnej. Katechizowani mogą w każdej polskiej świątyni parafialnej odnaleźć tekst Milenijnego Aktu Oddania, przywiezionego z Jasnej Góry przez delegację parafialną. Mają szansę również dzisiaj uczestniczyć corocznie w modlitwie o oddanie świata Maryi Matce Kościoła.

Zobowiązania wynikające z Jasnogórskich Ślubów Narodu, wskazane proroczo przez kardynała Stefana Wyszyńskiego, nadal oczekują na swoje wypełnienie przez nowe pokolenie Polaków, które podlega dzisiaj podobnym zagrożeniom, dotyczącym wiary, moralności i religii. Wszelka bowiem odnowa religijna domaga się w pierwszej kolejności odnowy poszczególnych ludzi, członków Kościoła.

Wielowektorowe dziedzictwo, jakie zostawił nowym pokoleniom Polaków kardynał Stefan Wyszyński, umiejętnie przestrzega przed realnymi zagrożeniami, jakie płyną dla każdej społeczności ludzkiej ze strony zlaicyzowanego środowiska i potęgowane są sytuacjami, w których brak jest prawdziwych przewodników na drogach wiary. Spuścizna ta posiada niebagatelną oryginalność i teologiczną poprawność, które odnoszą się wprawdzie do przeszłości, ale ze zdumieniem należy stwierdzić, że nie można im odmówić aktualnej siły przekonywania i rozwojowego potencjału. 


\section{BIBLIOGRAFIA}

Bartnik, Czesław (red.). Chrześcijańska nauka o narodzie wedtug prymasa Stefana Wyszyńskiego. Lublin: Redakcja Wydawnictw Katolickiego Uniwersytetu Lubelskiego, 1982.

Bartnik, Czesław. Matka Boża. Lublin: Towarzystwo Naukowe KUL, 2003.

Courtois, Stéphan (red.). Czarna księga komunizmu. Warszawa: Wydawnictwo AA, 1999.

Jan Paweł II. „Homilia w czasie liturgii Słowa (Częstochowa 2 czerwca 1997)”. W Jan Paweł II. Pielgrzymki do Ojczyzny, red. Janusz Poniewierski, 939-942. Kraków: Wydawnictwo Znak, 2005.

Kardynat Stefan Wyszyński. Droga życia i postugi pasterskiej, red. R. Czekalski. Warszawa: Wydawnictwo Naukowe UKSW, 2021.

Kardynał Stefan, Wyszyński. „Żywa wiara w potęgę Maryi była dla niego zobowiązaniem. 23 października 1967". W Kardynat August Hlond Prymas Polski, red. Wojciech Necel, 16-31. Poznań: Wydawnictwo Święty Wojciech, 1993.

Konopka, Hanna. 17 lat nauczania religii w Polsce Ludowej (wybór dokumentów). Białystok: Wydawnictwo Uniwersytetu w Białymstoku, 1998.

Królikowski, Janusz. „Maryja - Matka Kościoła w nauczaniu kardynała Stefana Wyszyńskiego”. Collectanea Theologica 61(1991), 4: 81-105.

Laskowska, Małgorzata. „Postulaty etyczne dla mediów w publicystyce ks. Stefana Wyszyńskiego". Kultura - Media - Teologia 3(2010): 92-104

Lewandowski, Jerzy. „Wychowawcze aspekty Wielkiej Nowenny w nauczaniu kard. S. Wyszyńskiego". Chrześcijanin w Świecie 116(1983): 16-29.

List apostolski Patris corde Ojca Świętego Franciszka z okazji 150. rocznicy ogłoszenia Świętego Józefa Patronem Kościoła Powszechnego 8 grudnia 2020. Tarnów: Wydawnictwo Biblos, 2020.

„List pasterski Biskupów Polskich do rodziców, dzieci i młodzieży katolickiej o nauczaniu prawd wiary 2 września 1961”. W Listy Pasterskie Episkopatu 1945-2000. Część I, red. Piotr Libera, Andrzej Rybicki, Sylwester Łącki, 244. Marki: Wydawnictwo Michalineum, 2003.

Micewski, Andrzej. Kardynat Wyszyński prymas i mąż stanu. Paryż: Societe D’Editions Internationales, 1982.

Miziołek, Władysław. „Maryjna koncepcja duszpasterstwa kardynała Stefana Wyszyńskiego”. Ateneum Kapłańskie 97(1981): 255-276.

„Na zakończenie Ogólnopolskiego Nawiedzenia Obrazu Matki Boskiej Jasnogórskiej 27-28 czerwca 1980ę. W Listy Pasterskie Episkopatu 1945-2000. Część II, red. Piotr Libera, Andrzej Rybicki, Sylwester Łącki, 1293-1298. Marki: Wydawnictwo Michalineum, 2003.

Ryszka, Czesław. Zwyciężyłaś, zwyciężaj. Matka Boża w dziejach narodu polskiego. Częstochowa: Edycja Świętego Pawła, 2003.

Siedlarz, Jan. „Wielka Nowenna Tysiąclecia - program społeczny na dziś”. Currenda 151(2001): 599-617.

Tomziński, Jerzy. Dzieje Jasnej Góry i Cudownego Obrazu. Częstochowa: Wydawnictwo Paulinianum, 2015.

Uryga, Jan. Nigdym Ja ciebie ludu nie rzuciła. Włocławek: Wydawnictwo Duszpasterstwa Rolników, 2001.

Wyszyński, Stefan prymas Polski. Gody w Kanie. Paris: Societe D’Editions Internationales, 1962. 
Wyszyński, Stefan. „Dlaczego zaczynamy od Maryi. Przemówienie inauguracyjne podczas Kursu Maryjnego. Jasna Góra 6 października 1959”. W Stefan kard. Wyszyński Prymas Polski. Wszystko postawitem na Maryje, 164-172. Paris: Societe D’Editions Internationales, 1980.

Wyszyński, Stefan. Idzie nowych ludzi plemię. Poznań-Warszawa: Pallotinum, 2001.

Wyszyński, Stefan. Wielka Nowenna Tysiaclecia. Paris: Societe D’Editions Internationales, 1962.

Wyszyński, Stefan. Z rozważań nad kultura ojczysta. Warszawa-Poznań: Wydawnictwo Pallottinum, 1979.

Wyszyński, Stefan. „Znak jedności pasterzy Kościoła w Polsce: W dłoniach Maryi Wspomożycielki. (Przemówienie do Biskupów polskich w dniu ich oddania się Matce Boga Żywego. Warszawa 15 marca 1961". W Stefan kard. Wyszyński Prymas Polski. Wszystko postawitem na Maryję, 233-237. Paris: Societe D’Editions Internationales, 1980.

Wyszyński, Stefan. Wielka Nowenna Tysiąclecia. Paris: Societe D’Editions Internationales, 1962.

Zieliński, Zygmunt. „Zasady polityki państwa wobec Kościoła w Polsce w latach 1944-1956”. W Aparat ucisku na Lubelszczyźnie latach 1944-1956 wobec duchowieństwa katolickiego, red. Zygmunt Zieliński, 8-9. Lublin: Towarzystwo Naukowe KUL, 2000.

Żaryn, Jan. Dzieje Kościoła katolickiego w Polsce (1944-1989). Warszawa: Wydawnictwo Neriton, 2003

\section{WPŁYW KARDYNAŁA STEFANA WYSZYŃSKIEGO NA DUCHOWĄ PEDAGOGIZACJĘ NARODU}

\section{Streszczenie}

Wieloletnia aktywność w przestrzeniach religijnych, narodowych i społecznych narodu polskiego daje podstawę do tego, aby kardynała Stefana Wyszyńskiego umieścić wśród najwybitniejszych autorytetów osobowych w dwudziestym wieku w Polsce. Poprzez pełnioną posługę biskupią i prymasowską wywarł wpływ na losy narodu i Kościoła w potrójny sposób. Najpierw poprzez podejmowanie różnorakich działań duszpasterskich i katechetycznych, następnie przez wypowiadanie się na konkretne tematy społeczne, narodowe i patriotyczne oraz poprzez maryjną pedagogizację narodu. W nauczaniu oraz posłudze pasterskiej łączył ze sobą z powodzeniem wymiary teologiczne i społeczne. Jego teologiczna spuścizna została ukonkretniona w Jasnogórskich Ślubach Narodu oraz Wielkiej Nowennie, co stało się inspiracją dla podjęcia działań duszpasterskich, które skutkowały wprowadzaniem w życie Kościoła katolickiego w Polsce nauczania Soboru Watykańskiego II. Unikalny wpływ kardynała Stefana Wyszyńskiego na rozwój polskiej myśli teologicznej i katechizacji można zauważyć w dziedzinach duchowości i pobożności maryjnej, apostolstwa świeckich, patriotyzmu, teologii kapłaństwa oraz katolickiej nauki społecznej, zwłaszcza teologii pracy, kultury i narodu.

Słowa kluczowe: Stefan Wyszyński; teologia; pedagogizacja maryjna; patriotyzm; katolicka nauka społeczna. 